\title{
REGULATORY CONSIDERATIONS OF BIOSIMILARS AND CLINICAL DILEMA OF THEIR USE
}

\author{
Stavrik Genadieva Sonja, ${ }^{1}$ Grozdanova Aleksandra, ${ }^{2}$ Netkovska Ancevska Katerina, ${ }^{2}$ \\ Dimitrova Genadieva Magdalena, ${ }^{3}$ Dimitrov Gligor ${ }^{4}$ \\ ${ }^{1}$ University "Ss. Cyril and Methodius", Medical faculty Skopje, \\ University hematology clinic, Skopje, R. Macedonia \\ ${ }^{2}$ University "Ss. Cyril and Methodius", Faculty of Pharmacy Skopje, R. Macedonia \\ ${ }^{3}$ University "Ss. Cyril and Methodius", Medical faculty Skopje, \\ University gastroenetrology clinic, Skopje, R. Macedonia \\ ${ }^{4}$ University "Goce Delcev", Medical faculty Stip, R. Macedonia
}

Primljen/Received 19. 10. 2016. god.

Abstract: Biomedical products are complex molecules, produced by living cells. More accurately, they are molecules that are naturally produced in the human body, like hormones or growth factors, monoclonal antibodies, blood products, immunological medicinal products, sera and vaccines, allergens, and advanced technology products such as gene and cell therapy products. Copies of these drugs, known as biosimilars, are comparable but not identical and are not generic version of innovator biological products. Specific regulatory requirements and abbreviated registration process apply in the case of biosimilars, in order to demonstrate efficacy and safety profile and to prove that product is similar to the original biomedical product.

Like all medicines, biological medicines work by interacting with the body to produce a therapeutic outcome, but the mechanisms by which they do this may vary from product to product and through indications. Therefore the role of the physicians in treatment of patients with these complex medicinal products is particularly important.

Regulatory issues, manufacturing, safety, physicians have part in develop use of biosimilars as much as generic drugs. Even though, the most important factor for market of biosimilar are commercial factor, still, real clinical dilemma of use are present, so it is necessary to have clear regulatory framework and postmarketing data on the use of biosimilars.

Keywords: biosimilars, innovate product, monoclonal antibodies, regulatory.

\section{INTRODUCTION}

Biomedical products are drugs whose active substance is made by living systems (plant or animal cells,
Prihvaćen/Accepted 20. 01. 2017. god.

bacteria, viruses and yeast) and biological medicines are used to treat diseases and genetic disorders in humans. Biological drugs are well established in the treatment of many conditions with increasing use in future years. Many, but not all biological medicines, are made using genetically-modified cells. The global biologic industry has come a long way since its first drug Humulin, that has been awarded US Food and Drug Administration (FDA) approval in 1982 (1). Biological sales now account for about US\$92 billion and are expected to worth more than US $\$ 176$ billion by 2015 (2). Biosimilars are biological products that are similar, but not identical, to an innovator product that is already on market and its patent has expired (3).

Biosimilars is a drug that is designed to be similar to the existing biological reference drug. Due to the complex of biological products and manufacturing process, there will always be small differences in molecular structure, more than reference one. Each manufacturer has its own unique cell lines and develops its own proprietary (unique) manufacturing processes. It is noted that some biological medicines are produced by non-Biotechnology methods and are therefore not necessarily authorized through the centralized procedure. The production of biological medicines involves processes such as fermentation and purification. The manufacturing processes for biological medicines are very sensitive and it is vital that these are precisely controlled in order to obtain consistent results and to guarantee the safety and efficacy of the final product.

When all intellectual property protection and marketing exclusivity for the references drugs have expi- 
red, copying can be offered by other biotech company. The patent expire of many biological drugs will open the door for numbers of biosimilars to enter the market. Marketing approval legal regulation is much more complex issue than generic equivalents of reference drugs.

In order to innovating product enter the clinical use, clinicans should be aware of use biosimilars of some of the issues that have emerged during the development and approval of these products (4).

The aim of this article is to introduce and describe specific perplexities regarding the regulatory considerations of biosimilars and the clinical dilemma of their use, that often occurs in clinicians.

\section{CLINICAL DILEMMA OF USE}

From clinical point of view it is always interesting to share your experience with other clinicians and pharmacists, because there is no universal rule.

Monoclonal antibody was one of the biggest advancement in treating the hematologic malignant diseases. In November, 1999 in Journal of Clinical Oncology Ronald Levy published Karnofsky lecture: Immunotherapy of Lymphoma. He claimed "Monoclonal antibodies are the first example of the payoff for cancer treatment that comes from our knowledge of the immune system. Monoclonal antibodies were the product of a fundamental discovery and they are now changing the paradigm of how disease are diagnosed and treated"(5).

The goal of CD 20 targeted therapy is to kill B lymphocytes by the use of monoclonal antibodies (MoAbs) against the B cell specific human CD 20 molecule. As a clinicians we are aware that rituximab is a human-to-mouse chimeric monoclonal antiCD20 antibody. Rituximab acts via three different mechanisms: complement-dependent cytotoxicity (CDC), antibodydependent cellular cytotoxicity (ADCC), induction of apoptosis and complexity of interaction between these mechanisms. Today, rituximab is a mainstay in the therapy of a broad variety of B-cell malignancies, but we still do not understand the exact mechanism of action responsible for rituximab's anti-tumor effects (6).

In 1997 the first MoAb called rituximab was approved by US Food and Drug Administration, specifically for the treatment of patients with relapsed/refractory CD20 positive low-grade/follicular lymphoma (7). Today, nearly over two decades later, rituximab has become a benchmark of a target therapy and one of the biggest treatment successes in B-cell lymphoid malignances. So, today the standard of care for a vast majority of B-cell lymphoid malignant hematologic disease include rituximab as single agent or in combination with chemotherapy. Rituximab has enhanced the out- come of patients with B cell hematologic malignancies by the great deal and has become a part of a therapy for newly diagnosed patients with B-cell Non-Hodgkin lymphoma at the stage of diagnosis as well as for relapsed patients. The improvement in response rate, progression free survival and overall survival in patients treated with immunochemotherapy makes rituximab the standard for care of the patients with indolent B-cell lymphoma as well as for the B cell high grade lymphoma. Rituximab has greatly changed the manner in which B-cell NHL are treated. (8). After long term follow up data had been available to be analyzed and introduction of rituximab combined with chemotherapy translated into improved survival in patients with B-cell indolent and aggressive lymphoma. A combination of rituximab and an antracyline-based chemotherapy has been accepted as the standard of treatment for patients with any stage diffuse large B-cell lymphoma. Patients with follicular B-cell lymphoma, as the most frequent low-grade lymphoma, after induction therapy, should be treated with maintenance program after immunochemotherapy for two years with rituximab as a single agent.

So, there is no dough, that a huge cohort of patients has been successfully treated with rituximab. $\mathrm{Ri}-$ tuximab has been recognized as well-tolerated, relatively safe and very important often less invasive alternative in comparison with traditional mostly chemotherapy based therapies for those conditions. We must emphasize that these conclusions are based on a results gathered from multicenter randomized studies and the measuring of the efficacy of rituximab has been estimated through response rate, progression free survival and overall survival (9).

From clinical point of view, doctors can assess response rate of the treatment very early but there is a high risk of relapse, so response rate is not firm surrogate for estimating the therapeutically results. Progression free survival may not correlate to the overall survival. So, overall survival is the hardest to achieve but is the safest in order to estimate the effect of treatment of these patients. Sometimes we need follow-up of the lymphoma patients treated with rituximab for a long period of time, even a decade to clearly estimate the benefit of treatment. Every clinician will agree that only survival data will safely demonstrate equivalence (10).

Rituximab biosimilars are at an advanced stage of development and pharmacokinetic data seems identical. Having in mind that every monoclonal antibody is unique, meaning that only small structural change can have significant consequence in terms of efficacy, safety and immunogenicity. Moreover, much of the development and clinical experience gained from the generation and optimization of antibody clearly emphasized 
that assays might not be able to discriminate differences and safety may differ with impurity profile, so efficacy might not be transferable (11).

Many questions are waited to be answered. Do we have firm evidence or are we still in need of the robust clinical trials to ensure comfort among hematologist who treat malignant hematologic diseases. Based on the definition, that biosimilars are the agents that are similar but not identical to the reference biopharmaceutical monoclonal antibody-biosimilar have been introduced and described as products with well-established manufacture and structural characterization, with available potency assays, well established function, well known safety profile and well established efficacy profile (12).

From the practice points of view, legislative battles are still going on, so clinicians need to be active participants in such a debate. At the present moment there are no dilemmas whether clinicians have a huge clinical experience, but in some points still a limited understanding of the biosimilars, due to the fact of its origin, that is quite distinct from traditional generics. Clinical potential of monoclonal antibodies have to be increased by improving existing properties as a key strength of antibodies as therapeutic and it is still unmet need. A clinical imperative is to achieve a better outcome for patients and to target malignant cell with more potent and effective monoclonal antibody.

\section{REGULATORY CONSIDERATIONS OF BIOSIMILARS}

A generic drug is a less expensive copy of an innovator drug product. Generic can be produced when the patent on a drug has expired, for drugs which have never held patent, in countries where patent is not in force, so generic company can certify that the branded company patent is invalid or unenforceable. Generic drug applications are generally not required to include preclinical and clinical data to prove safety and effectiveness. The generic manufacture demonstrates only pharmaceutical equivalence and bioequivalence between generic and innovator products.

However, this approach cannot be applied to biosimilars, because the active substance of biological products is a collection of large protein isoforms and not a single molecular entity, as is generally true for conventional small- molecule drugs. Thus the active substances in two products are highly unlikely to be identical and, therefore, unlike generics, biosimilars are only similar and not identical to the innovator products. These differences imply that biosimilars should not be approved and regulated in the same way as conventional generic drugs.
The regulatory process for approval of biosimilars is more complex than for the generic innovator product because the design of a scientifically valid study to demonstrate the similarity of a highly process-dependent product is not easy. Further, the analytical tests currently available are not sophisticated enough to detect the slight but important structural differences between innovator and biosimilar products. Modest differences may have clinical implications and pose a significant risk to patient safety. Therefore, it is considered necessary that biosimilars must be assessed for clinical efficacy and safety by valid preclinical and clinical studies before marketing approval $(13,14,15,16)$.

The European Union (EU) has established a regulatory framework for the marketing authorization of biosimilars, based on comparative quality and clinical pharmacokinetic studies, nonclinical studies, clinical pharmacodynamic studies, and limited toxicology studies, as well as comparative clinical efficacy and tolerability studies. In the USA, a regulatory framework was established in 2010 (17). The market accessibility of biosimilars may reduce costs to patients and social security systems. In general, the literature expects biosimilar medicines to be around $15 \%$ to $30 \%$ cheaper. For instance, a European analysis observed that in 2009 , the percentage price difference between reference biopharmaceuticals and biosimilar medicines amounted to $14 \%$ for somatropin, $17 \%$ for erythropoietin, and $35 \%$ for filgrastim. The market accessibility of biosimilars is also motivated by key government objectives related to, for instance, building manufacturing capabilities within a country than reference biopharmaceutical medicines (18). In this respect, some European countries have implemented industrial policies to encourage the development of biological products (19). For example, even though Croatian guidelines do not permit the substitution of originator with biosimilars, data collected from Clinical Hospital Centre Rijeka, in the period 2014-2016, showed increased trend of infliximab biosimilars prescribing, while the market share for erythropoietin's and filgrastim's is more stable. That means that although procurement for some of the biosimilar medicines is regulated at the hospital level, still there is difference within market dynamic and different biosimilar therapy areas (20). Another study done to project drug cost savings from the introduction of biosimilar trastuzumab showed that savings and price discount only for this biosimilar medicine can be between $15 \%$ (0.26 million euros) up $35 \%$ (0.69 million Euros) (21).

Interchangeability and/or substitution of innovator drug with biosimilars is also a big clinical and regulatory challenge. Interchangeability refers to the prescription of a biosimilar in place of the reference prod- 
uct by prescribers, while substitution means that pharmacists are allowed to dispense a biosimilar (22). This is due to the assumption that generic drugs and reference drugs are considered identical molecules if they have demonstrated bioequivalence. But, since biosimilar drugs are not exact copies and the generic approach cannot be applied in this case, the discussion whether they can be substitutes of original biologics is still open. Interchangeability and substitution of biosimilars is not regulated buy any EU regulatory document and EMA does not have the authority to designate a biosimilar as automatically substitutable, so it is left to each member country to decide how this process is going to be defined (23). European Consensus document released by the European Commission notes that interchangeability implies an initiative or agreement by the prescriber, patients and pharmacist about switching decisions and changing therapy from one biologic product to another (24).

Substitution and interchangeability of biosimilars are closely tied to their naming because when doctors prescribe biologics by a unique identifier, and not by their INN, the substitution of a biosimilar product when dispensed by a pharmacist would likely occur much less often. In practice, substitution by a pharmacist of a biosimilar for a reference biopharmaceutical medicine in general is not allowed in any European country (25) and is not recommended by the World Health Organization or by medical societies. The major concern about interchangeability is that repeated switches between the biosimilars and the reference biological may increase immunogenicity, leading to adverse reactions. Even during pharmacovigilance the studies are typically designed on patient population and never follow a single patient, making it very difficult to track the status of interchangeability issues. Therefore, it would be difficult for regulatory bodies to certify that the drug is truly interchangeable without adequate data. There has been considerable debate over this issue in all regulatory agencies and the EU Generics Association claims that more than 12 countries have rules against automatic substitution. However, France has now permitted the switch of biosimilars and generics with the originals as part of a new Social Security Budget Legislation (article 47), which came into practice in January $1^{\text {st }}, 2014$ (26). Still, due to the concerning health risks and differences of biosimilars in relation to the reference product, giving uncertainty for prescribers and patients, the application of interchangeability and/or substitution is limited. Nevertheless, the use of biosimilars in the clinic practice may have a positive impact in the near future, leading the way towards adequate decisions (27).

\section{CONCLUSION}

The first generation of biomedical products manufactured using recombinant technologies was in the 1980 s, and they are now on the way to patent expiration. As a result research based and generic pharmaceutical companies are making effort to develop substitutes for original biologics, referred as biosimilars. Nevertheless, introducing a biosimilar to an innovator product is far more complex than introducing a generic equivalent to innovator product based on a new chemical entity. Biomedical products are produced by cells in culture which are more variable than chemical synthesis methods. However, for generic pharmaceuticals, it is impossible to generate the same or identical copy of an innovator product. The field of biosimilars presents more challenges such as: verification of similarity, compatibility of biosimilars and innovator, unique naming to various products, regulatory framework, marketing, intellectual property rights, and safety. EU countries through EMA had established a tied regulatory framework for the licensing of biosimilars, but still the questions of naming and nomenclature of biosimilars, interchangeability and substitution, pharmacovigilance and the degree of comparability between a biosimilar and the reference need to be considered. Also there is a need for more comparative studies in order to collect the data necessary to follow-up and evaluate uncertainties concerning the long term safety, effectiveness, and cost-effectiveness of a biosimilars.

\section{Conflict of interest}

The authors declare that there is no conflict of interest.

\section{Licensing}

This work is licensed under a Creative Commons Attribution 4.0 International (CC BY 4.0) Licence 


\title{
Sažetak
}

\section{RAZMATRANJE REGULATIVA BIOSIMILARA I KLINIČKE DILEME U NJIHOVOJ PRIMENI}

\author{
Stavrik Genadieva Sonja, ${ }^{1}$ Grozdanova Aleksandra, ${ }^{2}$ Netkovska Ancevska Katerina, ${ }^{2}$ \\ Dimitrova Genadieva Magdalena, ${ }^{3}$ Dimitrov Gligor ${ }^{4}$ \\ ${ }^{1}$ University "Ss. Cyril and Methodius", Medical faculty Skopje, University hematology clinic, Skopje, R. Macedonia \\ ${ }^{2}$ University "Ss. Cyril and Methodius", Faculty of Pharmacy Skopje, R. Macedonia \\ ${ }^{3}$ University "Ss. Cyril and Methodius", Medical faculty Skopje, University gastroenetrology clinic, Skopje, R. Macedonia \\ ${ }^{4}$ University "Goce Delcev", Medical faculty Stip, R. Macedonia
}

Biomedicinski proizvodi su kompleksni molekuli, koje stvaraju žive ćelije. Tačnije, to su molekuli koji se prirodno stvaraju u živom organizmu, kao što su hormoni ili faktori rasta, monoklonalna antitela, produkti krvi, imunološki proizvodi, sera i vakcine, alergeni, kao i proizvodi nastali zahvaljujući naprednim tehnologijama, kao što su geni i terapija ćelijskim produktima. Kopije ovih lekova, poznatije kao biosimilarni, su komparabilni, ali ne i identični, i nisu generička verzija inovativnih bioloških produkata. Specifični regulatorni zahtevi, kao i skraćeni proces registracije se primenjuje u slučaju biosimilarnih proizvoda, u cilju pokazivanja efikasnosti i sigurnosti profila i radi dokazivanja da je proizvod sličan originalnom biomedicinskom proizvodu.

\section{REFERENCES}

1. Gienentech Inc. Corporate Chronology. 1982. http:// www.gene.com/gene/about/corporate/history/timeline.html.

2. Global Biopharmaceutical Market Report (2010-2015) IMARC October 29, 2010: 234 pages. Pub ID: IMRC2849563.

3. Mc Kinnon RA, Lu CY. Biosimilars are not (bio)generics. Aust Prescr, 2009; 32(6): 146-7.

4. Ledford H. Biosimilar drugs poised to penetrate market. Nature. 2010; 468(7320): 18-9.

5. Levy R. Karnofsky Lecture: Immunotherapy of lymphoma. J Clin Oncol 1999; 17(11 suppl): 7-12.

6. van Meerten T, Hagenbeek A. CD20 - target therapy: The next generation of antibodies. Semin Hematol. 2010; 47(2): 199-210.

7. Sousou T, Friedberg J. Rituximab in indolent lymphomas. Semin Hematol. 2010; 47(2): 133-42.

8. Zwick C, Murawski N, Pfeundshuh M, German HighGrade Non-Hodgkin Lymphoma Study Group. Rituximab in High-Grade Lymphoma. Semin Hematol. 2010; 47(2): 148-55.

9. Reichert JM, Rosenweig CJ, Faden LB, Dewitz MC. Monoclonal antibody successes in the clinic. Nat Biotechnol. 2005; 23(9): 1073-8.

10. Hirsch BR, Lyman GH. Biosimilars: A cure to the U.S. health care cost conundrum? Blood Rev. 2014; 28(6): 263-8.

11. Jahn EM, Schneider CK. How to systematically evaluate immunogenicity of theraeutic proteins- regulatory considerations. N Biotechnol. 2009; 25(5): 280-6.
Kao i svi lekovi i biološki lekovi deluju tako što se resorbuju u organizmu i završavaju se terapeutskim ishodom, ali mehanizam delovanja zavisi od proizvoda do proizvoda. S toga, uloga kliničara u prepisivanju lekova ove vrste je od izuzetnog značaja.

Pitanja regulativa, proizvodnje, bezbednosti su pitanja koja se odnose na korišćenje biosimilara, kao i generičkih lekova. Iako su za distribuiranje biosimilara najbitniji komercijalni faktori, dileme kliničara su i dalje prisutne, tako da je neophodno da postoji tačan regulatorni okvir kao i postmarketinški podaci i instrukcije o korišćenju biosimilara.

Ključne reči: biosimilari, inovativni produkti, monoklonalna antitela, regulative.

12. Simoens S. Biosimilar medicines and cost-effectivness. Clinicoecon Outcomes Res. 2011; 3: 29-36.

13. Crommelin D, Bermejo T, Bissig M, et al. Pharmaceutical evaluation of biosimilars: important differences from generic low-molecular-weight pharmaceuticals. Eur J Hosp Pharm Sci. 2005; 11(1): 11-7.

14. Roger SD. Biosimilars: how similar or dissimilar are they? Nephrology (Carlton). 2006; 11(4): 341-6.

15. Roger SD, Mikhail A. Biosimilars: opportunity or cause for concern? J Pharm Pharmaceut Sci. 2007; 10(3): 405-10.

16. Schellekens H. Follow-on biologics: challenges of the žnext generation'. Nephrol Dial Transplant. 2005; 20(suppl 4): 31-6.

17. Mellstedt $\mathrm{H}$. The future of biosimilars. Hosp Pharm Europe. 2010; 49: 33-4.

18. Long M, Trout J, Akpinar P. Biosimilars: HGH to TNFS, how will payers respond? ISPOR 12th Annual European Congress; October 26, 2009; Paris, France.

19. Danzon PM, Furukawa MF. Prices and availability of biopharmaceuticals: an international comparison. Health Aff (Millwood). 2006; 25(5): 1353-62.

20. Stanic Benic M, Jakovac S, Zekic T, Vlahovic-Palcevski V. Trend of Biosimilars Prescribing In A Croatian Teaching Hospital. Clin Ther. 2016; 38(10S).

21. Cesarec A, Likić R. Budget impact analysis of biosimilar Trastuzumab for the treatment of breast cancer in Croatia. Appl Health Econ Health Policy. 2016 Oct 11. [Epub ahead of print]. 
22. European Generic Medicines Association. Biosimilars Handbook. 2nd ed. Brussels: European Generic Medicines Association, 2011.

23. Grozdanova A, Netkovska KA, Sterjev Z, Naumovska Z, Zarevski R, Dimovski A, et al. Biosimilar medical products licensing, pharmacovigilance and interchangeability. Pril (Makedon Akad Nauk Umet Odd Med Nauki). 2016; 37(1): 27-36.

24. Consensus Information Paper 2013. What you need to know about Biosimilar Medicinal Products. European Commission. Available at: http://ec.europa.eu/enterprise/sectors/healthcare/files/docs/biosimilars_report_en.pdf.

\section{Correspondence to / Autor za korespondenciju}

Prof Dr Sonja Genadieva Stavrik

University hematology Clinic

Medical faculty Skopje, R. Macedonia

Vodnjanska 17, 1000 Skopje, R. Macedonia

email:sgenstav@yahoo.com

tel: +38970222031
25. EMA. Questions and Answers on Biosimilar Medi-cines, 2012. Available from: http://www.ema.europa.eu/docs/ en_GB/document_library/Medicine_QA/2009/12/WC500020062.pdf.

26. France to allow biosimilars substitution. 2014. Available at: http://www.gabionline.net/Policies-Legislation/Franceto-allow-biosimilars-substitution/(highlight)/france $\% 20$ substitution.

27. Weise M, Kurki P, Wolff-Holz E, Bielsky MC, Schneider CK. Biosimilars: the science of extrapolation. Blood. 2014; 124(22): 3191-6. 